\title{
SEREIAS: UM RELATO DE EXPERIÊNCIA SOBRE DESIGN SOCIAL
}

Fabrício Vieira de Oliveira

Instituto Federal de Educação, Ciência e Tecnologia da Paraíba

fabri.v.eira@gmail.com

Renata Amorim Cadena

Instituto Federal de Educação, Ciência e Tecnologia da Paraíba

renata.cadena@ifpb.edu.br

Resumo: A permissividade da partilha do conhecimento a partir da valorização dos saberes individuais no processo de aplicação do projeto de Design Social Sereias da Penha estimularam a percepção do valor cultural existente nas regiões da praia da Penha e do Jacarapé. Comunidades localizadas no litoral de João Pessoa - PB, e marcadas por histórias e lendas em seu processo de formação, que perduram resistentes aos efeitos da globalização e da homogeneização cultural. A necessidade de obter um produto resultante das vivências de aplicação do Projeto Sereias da Penha, como elemento de partilha das experiências sobre o Design Social, culminou na elaboração de um "diário de bordo", em referência à cultura pesqueira da região e norteado pelas métricas do Design Editorial. O livreto envolve duas partes da experiência: uma estrutura composta por relatos das etapas do projeto, e outra de caráter mais subjetivo, que retrata um fluxo mental inspirado nas lendas (como a que dá nome ao projeto em si) e nas referências culturais das regiões que expõe o complexo e o poético percurso das experiências absorvidas no período de aplicação do projeto. A solução projetual foi gerar um livreto pequeno, que dependendo da orientação em que for aberto, é mais descritiva, apresentando as ações e a cronologia do projeto; ou mais subjetiva, próxima à transmissão lúdica sobre o imaginário coletivo dos envolvidos no Projeto Sereias da Penha e dos membros das comunidades. $\mathrm{O}$ desenvolvimento do livreto trilhou os caminhos da expressividade do que foi vivenciado e, para isso, fez uso de ilustrações desenvolvidas com as técnicas de aquarela e pontilhismo na transmissão lúdica do imaginário coletivo dos envolvidos no projeto, além de explorar a produção gráfica na escolha de papeis, formatos e encaixes, de forma a representar as cores, texturas, sensações e processos relacionados ao projeto Sereias da Penha.

Palavras-chave: Design Social, Design Editorial, Diagramação, Diário de bordo. 